DOI: https://doi.org/10.18485/bells.2016.8.19

UDC: 821.111(73).09-31 Franzen J.

Mihai Mindra"

University of Bucharest

Romania

\title{
A COGNITIVE NARRATOLOGY APPROACH TO THE AMERICAN NEOLIBERAL NOVEL: FIGURE VERSUS GROUND IN JONATHAN FRANZEN'S FREEDOM
}

\begin{abstract}
The paper discusses Jonathan Franzen's Freedom (2010) in the context of the American Neoliberal novel - a recent subgenre ${ }^{1}$ which builds upon the tradition of the 1970s - 1980s conspiracy-centred fictions and creatively transforms it into a set of literary productions focused on the significance of global capital on everyday American lives and political governance. By capitalizing on cognitive narratology theories on the (de)structuring of fictional storyworlds, predicated on various means of spatialization, I intend to examine how ideological and social spatiality works and why such an approach to text analysis would be useful for a close reading of literary texts.
\end{abstract}

Key words: Neoliberalism, American fiction, cognitive narratology, spatialization.

\footnotetext{
Email address: mihai.mindra@gmail.com

1 This literary subgenre encompasses work by Jennifer Egan, Dave Eggers, Joshua Ferris, Allegra Goodman, and Sam Lypsite, alongside Jonathan Franzen.
} 
In the 2013 Winter issue of Dissent, critic Jeffrey J. Williams defined a new political literary subgenre, embodied by the 1990s new wave of American fiction, as a distinct body of work which focuses on "the dominance of finance, the political power of the super-rich, and the decline of the middle class...this new wave tend[ing] to see government as subsidiary, with the main societal choices occurring within the economic sphere." (Williams 2013: 93) His essay ${ }^{2}$ foregrounds, as major representatives, fiction writers Jennifer Egan, Dave Eggers, Joshua Ferris, Jonathan Franzen, Allegra Goodman, and Sam Lypsite. Such authors critically engage with Neoliberalism, generally defined as Milton Friedman and Friedrich von Hayek's version of liberalism with an emphasis on self-regulating free markets, associated in the last three decades with the economic policies practiced by Ronald Reagan, Bill Clinton and George W. Bush ${ }^{3}$ and "aimed at deregulating national economies, liberalizing international trade, and creating a single global market." (Steger and Roy 2010: x)

My reading of the neoliberal global spatial representations relies on cognitive narratology, specifically on the concept of storyworld, a mental model of what the fictional world presented Ryan 1991: 13), as well as on spatialization, as one means through which the author / narrator creates a sense of space in the fictional text. As David Herman argues "In trying to make sense of a narrative, interpreters attempt to reconstruct not just what happened but also the surrounding context or environment embedding storyworld existents (Herman 2008: 154), their attributes, and the actions and events in which they are involved." (Herman 2008: 570). Herman discusses the concept of 'spatialization' as resulting from 'six key ideas growing out of work on language and space': deictic shift; ${ }^{4}$ figure versus

2 For another definition of this subgenre please see Michaels (2011).

3 Neoliberalism as a concept partially overlaps with Jameson's understanding of the multinational/late stage of capitalism or postmodernity (Jameson 2001; La Berge 2015).

4 'Deictic shift' refers to the literary discourse device through which a storyteller prompts his/her interlocutor/reader to relocate from his/her HERE and NOW to the alternative space-time coordinates of the storyworld (Herman 2002: 270. 
ground $;{ }^{5}$ regions, landmarks, and paths; ${ }^{6}$ topological versus projective locations; $;^{7}$ motion verbs $;^{8}$ and the WHAT versus the WHERE Systems. ${ }^{9}$ The use of such criteria in a fictional text analysis can demonstrate how narratives enable 'cognitive mapping', i.e. 'the process by which things and events are mentally modelled as being located somewhere in the world.' (Herman 2002: 265)

For the purpose of this paper, I will focus on the "figure versus ground" (or "located object versus reference object") and its representation in Jonathan Franzen's novel. According to Herman, the relationship between figure/located object and ground/reference object is basic to the process of narration. Storyworlds contain focused-upon participants, objects and places, i.e. "figures" and a background against which those focused-upon entities stand out, i.e. ground. By structuring the world in this way stories make it humanly cognizable. "On this view, narrative is...an overarching communicative, interactional, and cognitive environment thanks to which modules can be brought into a systematic, mutually enabling and constraining relationship with one another." (Herman 2002: 277).

David Herman explains the concepts of "figure" and "ground" at the level of physical narrative space and grammatical representation with the help of a fragment from George Eliot's novel Daniel Deronda (1876), which exemplifies the extensively and minutely descriptive style of the nineteenth - century Victorian novel, where the social and individual psychological elements were revealed via the intricate relationships between settings and characters expressed through specific prepositions that indicated the

5 The semantic structure of spatial expressions can be thought of as a dependency relation between located objects (i.e. figures) and reference objects (i.e. grounds). In the process of narration storyworlds are constructed by authors and perceived by readers as imaginative spaces inhabited by figures moving/acting against a background (i.e. ground) (Herman 2000: 346-347).

6 The meaning of landmarks, regions, and paths in cognitive narratology is similar to those used in charting any spatial trajectories (Herman 2000: 279).

7 Topological locations are invariant whereas projective ones vary with the author's/ narrator's angle of vision (Herman 2000: 280).

8 Motion verbs are instrumental for the construction of storyworld cognitive maps. They express projective locations and paths taken by characters/participants that move from place to place within the storyworld. They may signal and trigger a deictic shift and set the space-time coordinates of the deictic center to which the reader is prompted to relocate (Zubin and Hewitt 1995: 129-155; Herman 2000: 282).

9 The WHAT system is concerned with objects (object shapes, names, and kinds), whereas the WHERE system is made out of places (Herman 2000: 284-285). 
interpersonal emotions of the participants. The post-postmodern twentyfirst century American novel replaced the material space movements and relatedness, so common with nineteenth-century realist fiction, with those inside the area of consciousness. "Figure" and "ground" are narratively constructed within this type of virtual space, through renditions of the main characters' mental representations of the storyworld they inhabit, narratively expressed in $3^{\text {rd }}$ person diary-style conventions (Patty Berglund, neé Emerson) or semi-omniscient heterodigetic storytelling (unnamed narrator). The American neoliberal novel thus imbues the fictional space of human consciousness with "figure" and "ground" elements of Neoliberal ideology that the reader can intellectually/imaginatively perceive.

In an unevenly, unconventionally organized novel matter (three unequal parts, one Steinian, self-analyzing $3^{\text {rd }}$ person four-chapter diary, lopsidedly straggling the six hundred-ish "baggy monster", six subparts) one tells mimetically and diegetically (all extra, intra and meta variants), in Genette-wise analeptic and proleptic hetero and homodiegetic episodes, the story of the liberal middle-class Berglunds: William, wife Patty, sibling offspring Joey and Jessica, as well as the husband's friend and wife's lover and rock star Richard Katz. These characters are depicted in Minnesota and Washington D.C. to and fro movements, over almost three decades, covering the Ronald Reagan to the beginning of Barak Obama's administrations. William grows neoliberal almost unaware, in a series of existentially unexamined choices, Patty stays left liberal and so does Richard Katz, if only more vocal in his deeply ingrained anti-Republican beliefs.

The most illustrative sample of narrative focus on what Herman calls "localized areas of concern" (Herman 2002: 275), in Franzen's text, is the part which focuses on the 1980s-2010 neoliberal America, where "figure" and "ground" storytelling spatial principles make this period cognizable, Part II "2004", subsection entitled "Mountaintop Removal." The subtitle refers to an infamous surface mining procedure practiced in the period: mountain tops are removed in order to extract coal freely. Paradoxical ecologist William Berglund reached the conclusion that the government and the average American will never be able to act ecologically responsible and efficient, while the wealthy are both interested, as enjoyers of earthly possessions, and capable of doing it. Supported financially by billionaire mogul Vin Haven, Berglund creates the Cerulean Mountain Trust meant to preserve the disappearing Cerulean Warbler species by purchasing coal rich mountainous territory where coal companies were allowed to drill 
Mihai Mindra: A Cognitive Narratology Approach to the American Neoliberal Novel...

the earth dry and then leave the territory for the Trust to keep the bird and protect its species. This moment in the novel represents its political/ ideological crux: the liberal left ecological vs. neoliberal of the novel, the "figure" / located object expressed in this section qua interpretation in both mimesis (showing) and diegesis (telling) narrative manner of Walter Berglund's slow, unconsciously existential and ideological conversion. It is expressed openly in the explicit meeting Walter, supported by BengaliAmerican erotically involved assistant Lalitha, arranges with Richard in order to obtain his cooperation, as a famed rock ' $n$ ' roll musician in advertising the Cerulean Trust ecological campaign.

'I work for a guy named Vin Haven who's based in Houston, he's a big oil-and-gas guy. His wife's dad was an old-school Republican. Served under Nixon, Ford, and Reagan.' [...] The cerulean warbler, Walter said, bred exclusively in mature temperate hardwood forests, with a stronghold in the central Appalachians. There was a particularly healthy population in southern West Virginia, and Vin Haven, with his ties to the nonrenewable energy industry, had seen an opportunity to partner with coal companies to create a very large, permanent private reserve for the warbler and other threatened hardwood species. The coal companies had reason to fear that the warbler would soon be listed under the Endangered Species Act, with potentially deleterious effects on their freedom to cut down forests and blow up mountains. Vin believed that they could be persuaded to help the warbler, to keep the bird off the Threatened list and garner some much-needed good press, as long as they were allowed to continue extracting coal. And this was how Walter had landed the job as executive director of the Trust. (Franzen 2011: 222 - 224)

The contradictory, almost oxymoronic ideological compound of Walter's obsessive ecologism and market oriented strategy is psychologically explained to contribute to the authenticity of his humanity, as Franzen conceived it, in alternate "figure/located object" components of the novelistic narrative, which evolve out of the "ground/reference object" of his unsuccessful family life, as commented upon by a heterodiegetic narrator, also posing as spokesman of Walter's consciousness, in Part II "2004," section “The Nice Man's Anger": 
To Walter the message of every single radio station was that nobody else in America was thinking about the planet's ruination. The God stations and the country stations and the Limbaugh stations were all, of course, actively cheering the ruination; the classicrock and news-network stations continually made much ado about absolutely nothing; and National Public Radio was, for Walter, even worse. Mountain Stage and A Prairie Home Companion: literally fiddling while the planet burned! And worst of all were Morning Edition and All Things Considered. The NPR news unit, once upon a time fairly liberal, had become just another voice of center-right free-market ideology, describing even the slightest slowing of the nation's economic growth rate as "bad news" and deliberately wasting precious minutes of airtime every morning and evening-minutes that could have been devoted to raising the alarm about overpopulation and mass extinctionson fatuously earnest reviews of literary novels and quirky musical acts like Walnut Surprise. And TV: TV was like radio, only ten times worse. The country that minutely followed every phony turn of American Idol while the world went up in flames seemed to Walter fully deserving of whatever nightmare future awaited it. He was aware, of course, that it was wrong to feel this way-if only because, for almost twenty years, in St. Paul, he hadn't. He was aware of the intimate connection between anger and depression, aware that it was mentally unhealthy to be so exclusively obsessed with apocalyptic scenarios, aware of how, in his case, the obsession was feeding on frustration with his wife and disappointment with his son. (Franzen 2011: 334)

The ground/reference object of this revelation for both reader and participant/character Richard Katz is constituted by a series of narrative elements constructed both diegetically and mimetically. At the diegetic level, a heterodiegetic semi-omniscient storyteller talks from inside Richard's guilt-ridden consciousness, due to a brief but complex affair with Patty, about his saturation with music playing and stardom accompanied by a vague wish to obtain some kind of redemption, presumably followed by a change of life initiated by his reconnecting with best friend Walter Berglund. On the mimetic plan, in the same section, things start happening in the direction wished by this character. After a brief depressive period, in 2003, Katz returns to his old hobby in order to earn a living and starts 
Mihai Mindra: A Cognitive Narratology Approach to the American Neoliberal Novel...

building decks in Jersey City, New Jersey until, he resumes contact with Walter, following the latter's insistent calls:

Behind him, on a counter crowded with unwashed dishes, his landline rang. The readout said Walter Berglund. 'Walter, my conscience,' Katz said. 'Why are you bothering me now?' He was tempted, in spite of himself, to pick up, because he'd lately found himself missing Walter...Katz couldn't have said exactly why Walter mattered to him. No doubt part of it was simply an accident of grandfathering: of forming an attachment at an impressionable age, before the contours of his personality were fully set. Walter had slipped into his life before he'd shut the door on the world of ordinary people and cast his lot with misfits and dropouts. (Franzen 2011: 217-218)

Patty Berglund's intimate perceptions of her husband's ideological transformation, which are strewn all over the book matter, but especially in her autobiography inserted in the novel, completes the ground/reference object material against which the "figure/located object" stands out in "Mountaintop Removal." One such example is as follows:

And so Walter became competitive. Within weeks of the release of Nameless Lake, he was flying to Houston for his first interview with the megamillionaire Vin Haven, and a month after that he began to spend his work weeks in Washington, D.C. It was obvious to Patty, if not to Walter himself, that his resolve to go to Washington and create the Cerulean Mountain Trust and become a more ambitious international player was fueled by competition. (Franzen 2011: 121)

As illustrated above, in this sample brief presentation of two components of narrative spatiality, cognitive narratology provides the opportunity to connect to a creative/artistic rendition of an ideology originating and unfolding in the private lives, psychology and relationships of emblematic fictional characters. 


\section{References}

Franzen, Jonathan (2011). Freedom. London: Fourth Estate.

Herman, David (2002). Story Logic. Problems and Possibilities of Narrative. University of Nebraska Press: Lincoln and London.

Herman, David (2008). Existent. In David Herman, Manfred Jahn, MarieLaure Ryan (eds.) Routledge Encyclopedia of Narrative Theory, London, New York: Routledge, 154.

Herman, David (2008). Storyworld. In David Herman, Manfred Jahn, Marie-Laure Ryan (eds.) Routledge Encyclopedia of Narrative Theory, London, New York: Routledge, 569-570.

Jameson, Frederic (2001). Notes on Globalization as a Philosophical Issue. In Fredric Jameson and Masao Miyoshi (eds.), The Cultures of Globalization, Durham and London: Duke University Press, 54-77.

La Berge, Leigh Claire (2015). Scandals and Abstraction: Financial Fiction of the Long 1980s. Oxford, New York: Oxford University Press.

Michaels, Walter Benn (2011). Model Minorities and the Minority Model. In Leonard Cassuto, Clare Virgina Eby and Benjamin Reiss (eds.), The Cambridge History of the American Novel, Cambridge, New York: Cambridge University Press, 1016-1030.

Ryan, Mary-Laure (1991). Possible Worlds, Artificial Intelligence and Narrative Theory. Bloomington: Indiana University Press.

Steger, Manfred B. and Ravi K. Roy (2010). Neoliberalism: A Very Short Introduction. Oxford, New York: Oxford University Press.

Williams, Jeffrey J. (2013). The Plutocratic Imagination. Dissent, 60.1, 93-97.

Zubin, David A. and Lynne E. Hewitt (1995). The Deictic Center: A Theory of Deixis in Narrative. In Judith Duchan, Gail Bruder and Lynne Hewitt (eds.), Deixis in Narrative. A Cognitive Science Perspective, New York and London: Routledge, 1995, 129-155. 